UDC 634.711(497.11)"2006/2016"

Review paper

doi: 10.5937/AASer1947019G

Acta Agriculturae Serbica, Vol. XXIV, 47(2019); 19-25

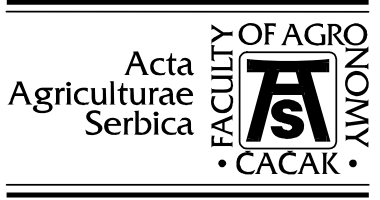

\title{
The Raspberry - An Analysis of Production in the Republic of Serbia from 2006 to 2016
}

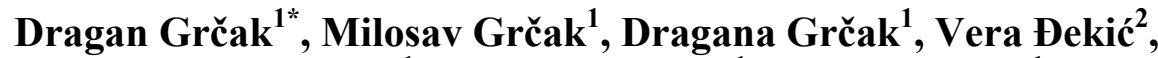 \\ Miroljub Aksić ${ }^{1}$, Katerina Nikolić ${ }^{1}$, Slaviša Gudžić ${ }^{1}$ \\ ${ }^{1}$ University of Priština, Faculty of Agriculture, Lešak, Serbia \\ ${ }^{2}$ Center for Small Grains, Kragujevac, Serbia \\ Corresponding author:dragan.grcak@pr.ac.rs
}

\begin{abstract}
Raspberry production has a long tradition in the Republic of Serbia, and the raspberry is the most economically important berry crop. According to data for the period from 2006 to 2016, the Republic of Serbia was ranked fourth in the world in the production of this fruit crop. The paper presents an analysis of raspberry production in the Republic of Serbia using statistical data from the previous years, which were compared with 2016 data. For comparison and analysis, we used the data presented on the FAOSTAT statistical database website and the Statistical Office of the Republic of Serbia (RZS) website. The analysis of the available data for the period 2006-2016 shows that the total yield of raspberries in this period varied, as did yield in tonnes per hectare, which ranged from 5.3 to 6 tonnes, depending on year. A sudden decrease in total yield in 2012 and in all subsequent years until 2016 was also observed. This was caused by a sudden reduction in the area under raspberries.
\end{abstract}

Keywords: raspberries, Serbia, production.

\section{Introduction}

Based on the FAOSTAT data for the period 2006-2016, the supremacy of Europe in raspberry production is obvious. Europe produces nearly three-quarters of the total quantity of raspberries on an annual basis, convincingly ranking first with $72.2 \%$, followed by South and North America, which together account for 
$25.3 \%$ of the total world raspberry production. Asia has a share of $2.5 \%$, while Oceania and Africa are the last with $0.1 \%$ each. The total world production of raspberries in 2016 amounted to 795249 tonnes. The primacy of Europe in the entire world production can primarily be seen in the fact that six countries from this continent are among the top ten world producers of raspberries. The Russian Federation ranks first with 146763.82 tonnes, followed by Poland with 96,911.91 tonnes, the United States (88 226.64 tonnes) and the Republic of Serbia with an average annual production of 75 499.73. Figures 1 and 2 present the annual average production of raspberries in the world in the period 2006-2016.

Raspberries hold an important position in the overall fruit production in the Republic of Serbia as they are economically the most important berry fruit (Petrović et al. 1996; Milošević 2001). The tradition of growing raspberries in Serbia is morethan a centuryold (Kljajić et al., 2013). The commodity production of raspberries began after the First World War (around 1920) (Kljajić, 2017). However, more intensive cultivation of raspberries has started in recent decades, assuming greater economic importance than an ordinary garden crop (Keserović et al., 2016; Keserović et al., 2014). This is supported by the fact that raspberry production in Serbia in 1946 amounted to only 120 tonnes (Šoškić 1995).

The objective of this paper is to analyze raspberry production in the Republic of Serbia using economic data for the period 2006-2016.

\section{Production share of Raspberries by region \\ Sum $2006-2016$}

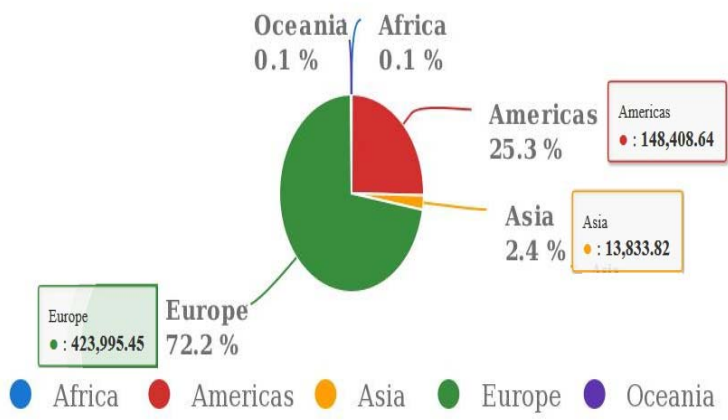

Source: FAOSTAT (Jan 31, 2018)

Graphic 1. Share of raspberry production by region, 2006-2016

(FAOSTAT)

Despite favorable natural and economic conditions, Serbian agricultural production in the fruit-growing sector is characterized by extensive nature, which can be determined on the basis of relatively low and irregular yields. The high productivity of raspberries and their long-term export to the world market have 
significantly influenced the development and intensification of their production in Serbia. The realization of economic interests of raspberry producers was crucial for investment in perennial raspberry plants (Kljajić, 2014).

According to the 2012 data, about 80000 farms, 250 refrigerator trucks and about 100 processing plants were involved in raspberry production in Serbia (Djurković, 2012).

In the best years, up to 20 tonnes of raspberries per hectare were harvested in the region of Arilje. Under ideal conditions, up to 24 tonnes of raspberries per hectare can be produced (USAID, 2008).

\section{Production of Raspberries: top 10 producers}

\section{Sum 2006 - 2016}

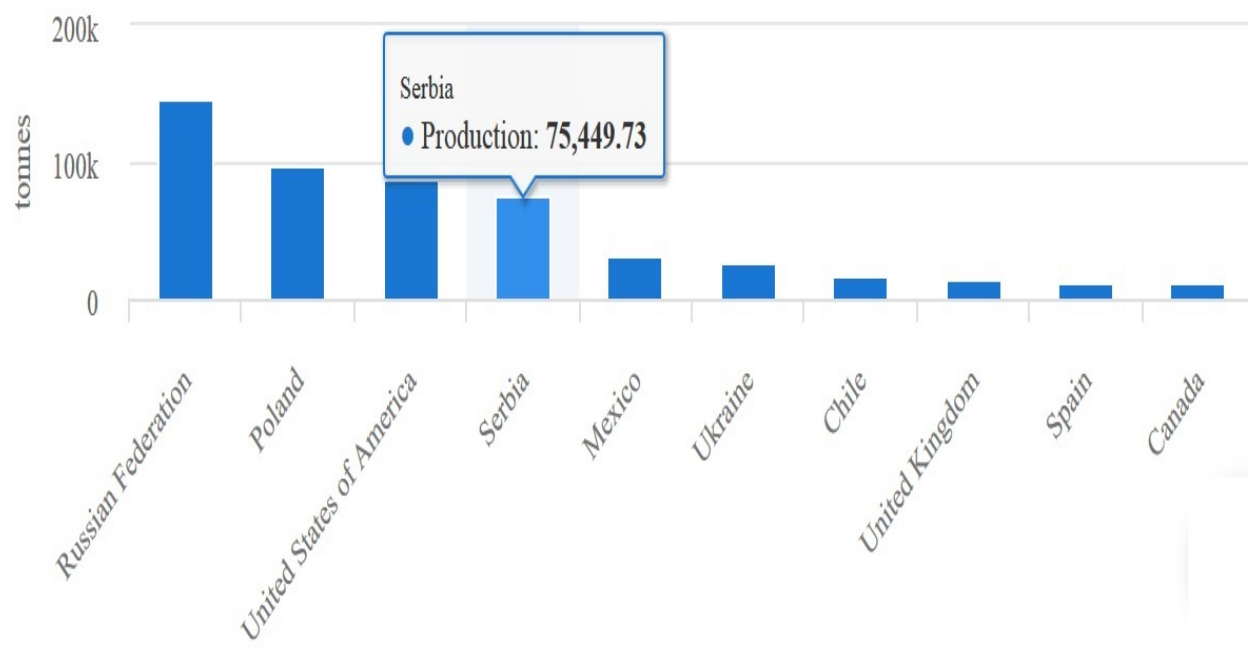

Production

Graphic 2. Ten largest producers of raspberries in the world, 2006-2016, according to FAOSTAT

\section{Material and Methods}

According to the data of the Statistical Office of the Republic of Serbia (Table 1), a total yield of $61875 \mathrm{t}$ of raspberries from a productive area of 11041 ha was registered, with an average yield of $5.6 \mathrm{t}$ per hectare; out of this, less than $0.1 \%$ of raspberries were produced in Northern Serbia (Belgrade and Vojvodina regions), while $97 \%$ of raspberries were produced in the area of 
Šumadija and Western Serbia, and about 3\% in Southern and Eastern Serbia. For comparison of raspberry production in recent years, the data available on the Statistical Office of the Republic of Serbia (RZS, 2018) website and the FAOSTAT statistical database were used.

Table 1. Raspberry production in the Republic of Serbia in 2016 (RZS)

\begin{tabular}{|l|c|c|c|}
\hline & $\begin{array}{c}\text { Area harvested } \\
\text { (ha) }\end{array}$ & Production (t) & Yield (t/ha) \\
\hline Republic of Serbia & 11041 & 61875 & 5.6 \\
\hline Serbia - NORTH & 38 & 282 & 7.4 \\
\hline Belgrade region & 5 & 44 & 7.2 \\
\hline Vojvodina & 33 & 238 & 8.8 \\
\hline Serbia - SOUTH & 11002 & 61593 & 5.6 \\
\hline $\begin{array}{l}\text { Sumadija and Western } \\
\text { Serbia }\end{array}$ & 10513 & 59655 & 5.7 \\
\hline $\begin{array}{l}\text { Eastern and Southern } \\
\text { Serbia }\end{array}$ & 489 & 1938 & 4 \\
\hline
\end{tabular}

\section{Results and Discussion}

A comparison of indices of total raspberry yields in Serbia in 20062016, which are available on the FAOSTAT website, is presented in Figure 3.

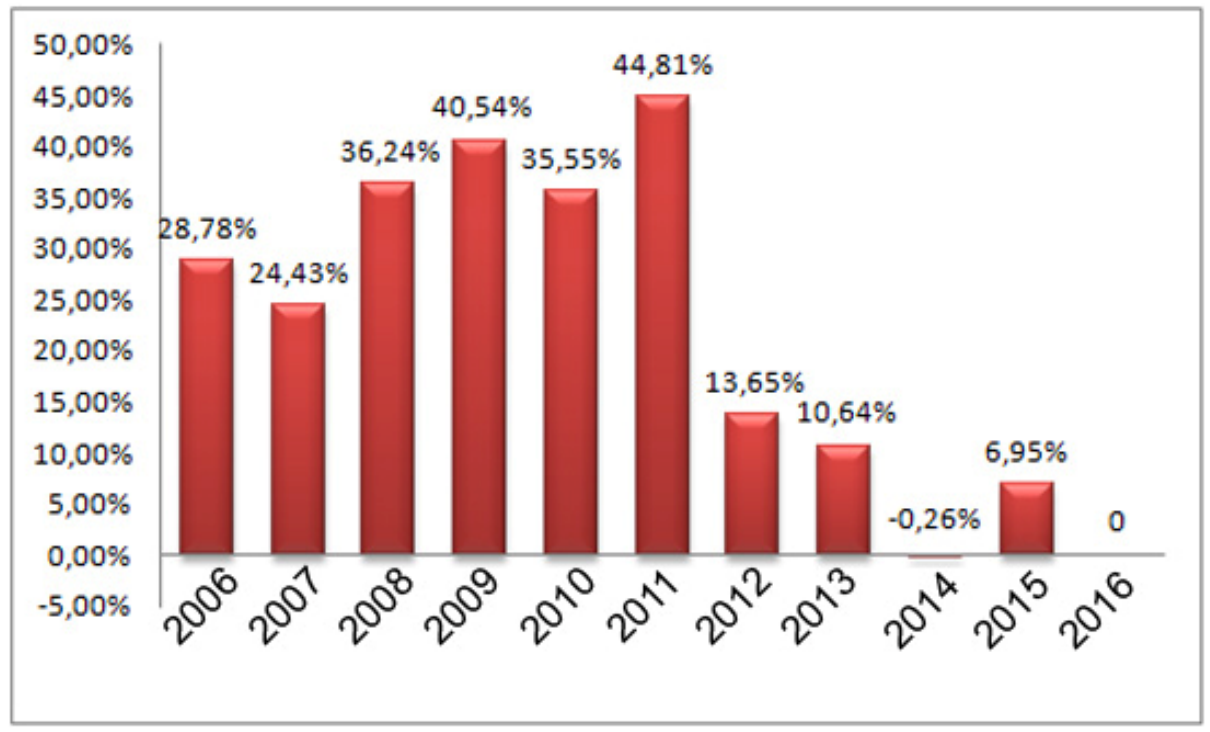

Graphic 3. Indices of total yields of raspberries in Serbia from 2006 to 2016, according to FAOSTAT 
The comparison ofindices of total yields of raspberries in Serbia shows that the yield, with minor fluctuations, increased up to 2011, and a large decrease occurred in 2012. In 2012, due to adverse weather conditions in some areas under raspberries in Serbia, the average yield decreased to around $2.5 \mathrm{t} \mathrm{ha}^{-1}$. Considering the reduction in the area under raspberries in Serbia, which occurred in 2012, by a whopping 4313 hectares (2016 was compared to 2011, when the area under raspberries was the largest for this period of time), the decrease is understandable. In addition, Figure 3 shows the maximum total yield of $40.81 \%$ in 2011 in relation to the most recent data, while the lowest total yield was registered in 2014 and was $0.26 \%$ lower compared to the 2016 results. The chart also shows that, in comparison to 2016, worse results were achieved only in 2014, when it comes to the total yield.

In the period 2007-2011, raspberry production was the fastest-growing production in Serbia. Ninety to $95 \%$ of raspberries grown in Serbia are North American Willamette raspberries.

New varieties of raspberries have been produced in Serbia, including 'Large Remontant', 'Gradina' and 'Podgradina'. An objective of raspberry cultivation is to create varieties without thorns, which are more productive and have a longer harvest season and increased resistance (Mitrović et al., 2007).

Keserović et al. (2007) indicate the beginning of collection and preservation of genotypes and varieties of berry fruits in Serbia.

The raspberry is a sensitive fruit speciesrequiring regular protection throughout the year (Dobrivojević and Krsmanović 2006; UNDP, 2015).

Table 2. The data on areas, production and average yield of raspberries in the Republic of Serbia (RSZ)

\begin{tabular}{|l|c|c|c|}
\hline Year & $\begin{array}{c}\text { Area harvested } \\
\text { (ha) }\end{array}$ & Production (t) & Yield (t/ha) \\
\hline 2006 & 15.024 & 79.680 & 5.3 \\
\hline 2007 & 14.496 & 76.991 & 5.3 \\
\hline 2008 & 14.680 & 84.299 & 5.7 \\
\hline 2009 & 14.957 & 86.961 & 5.8 \\
\hline 2010 & 15.171 & 83.870 & 5.5 \\
\hline 2011 & 15.354 & 89.602 & 5.8 \\
\hline 2012 & 11.996 & 70.320 & 5.9 \\
\hline 2013 & 12.025 & 68.458 & 5.7 \\
\hline 2014 & 11.041 & 61.715 & 5.6 \\
\hline 2015 & 11.041 & 66.176 & 6 \\
\hline 2016 & 11.041 & 61.875 & 5.6 \\
\hline
\end{tabular}


Table 2 shows that the decrease in total yield was largely due to the reduction in the productive area under this type of fruit. There were no major changes in total yield in the last 5 years of the period analyzed, but the fact remains that the productive area under raspberries sharply decreased starting from 2012, while in the period 2006-2012 the total area under raspberries remained unchanged, with minor variations. According to the data of the Republic Hydrometeorological Service of Serbia for $2015 / 2016$, due to the very warm summer and autumn, which were significantly warmer than average conditions, and due to heavy rainfall, conditions for the development of fungal and bacterial diseases were satisfied.

\section{Conclusion}

The comparison of indices of total yields of raspberries from 2006 to 2016 in the Republic of Serbia, shows a decline in raspberry production in 2012 compared to previous years. A yield of $61857 \mathrm{t}$ in a productive area of 11041 ha was registered in 2016. The highest yield was in 2011 and it amounted to $89602 \mathrm{t}$. Compared with this year, the previous three years were also good, while all subsequent years were consistently bad, with minor deviations. In the last several years of the period analyzed, the total area under raspberries remained unchanged, with some fluctuations in crop yields caused by climatic conditions, pests and diseases.

\section{References}

Dobrivojević K., Krsmanović D. (2006): Raspberry and its protection.

FAOSTAT (Food and Agriculture Organization of the United Nations). http://www.fao.org/faostat/en/ (Accessed: 29.1.2018. at 18:00)

Keserović Z., Gvozdenović D., Cindrić P., Paprić Đ., Korać N., Ognjanov V., Ninić-Todorović J., Kuljančić I., Gološin B., Cerović S., Medić M., Magazin N., Bijelić S. (2007): Naučnoistraživački rad Instituta za voćarstvo i vinogradarstvo u Novom Sadu (1947-2007). Contemporary Agriculture, 56 (6): 1-17.

Keserović Z., Magazin N., Kurjakov N., Dorić M., Gošić J. (2014): Popis poljoprivrede 2012: Poljoprivreda u Republici Srbiji-Voćarstvo. Republicki zavod za statistiku, Beograd, Srbija, 94.

Keserović Z., Magazin N., Milić B., Dorić M. (2016): Voćarstvo i vinogradarstvo (deo voćarstvo). Univerzitet u Novom Sadu. Poljoprivredni fakultet, Novi Sad.

Kljajić N. (2014): Efikasnost investicija u proizvodnji maline. Monografija. Institut za ekonomiku poljoprivrede. Beograd.

Kljajić N. (2017): Production and export of raspberry from the Republic of Serbia. Ekonomika, 63 (2): 45-53. 
Kljajić N., Vuković P., Arsić S. (2013): Tendencies related to the production of raspberries in the Republic of Serbia. Economics of Agriculture/Ekonomika Poljoprivrede, 60 (1).

Milošević T. (2001): Stanje i perspektiva proizvodnje maline i kupine u Republici Srbiji 2001. Acta Agriculturae Serbica, 6 (11): 71-75.

Mitrović M., Ogašanović D., Tešović Ž., Plazinić R., Marić S., Lukić M., Radičević S., Milinković V., Leposavić A. (2007): Rezultati oplemenjivanja voćaka u Institutu za voćarstvo u Čačku. Contemporary Agriculture, 56 (6): 50-61.

Petrović S. M., Lučić P., Milošević T. (1996): Ekonomski značaj proizvodnje jagodastog voća u centralnoj Srbiji u periodu od 1971-1994. godine. Ekonomika poljoprivrede, 43 (1): 65-76.

RZS (Republic Institute for Statistics): http://www.stat.gov.rs/WebSite/Default.aspx (Accessed on 30/1/2018)

Šoškić A. (1995): Malina. Beograd: Nolit .

Djurkovic, M. (2012). SWOT analysis of Serbia's raspberry sector in the competitive marketplace. Norwegian University of Life Sciences.

UNDP (2015): United Nations Development Programme. Gajenje malina. Initiative for agricultural development of Kosovo. Inicijativa za poljoprivredni razvoj Kosova.

USAID (2008): "Marketing Research for Kosovo Berries Production", Contract No. AFP-I00-03-00030-00, TO \#800, Chemonics International Inc., United States Agency for International Development, Kosovo Cluster and Business Support project. http://pdf.usaid.gov/pdf_docs/PNADL718.pdf. 